\title{
13. DINOFLAGELLATE CYST ECOSTRATIGRAPHY OF PLIOCENE-PLEISTOCENE SEDIMENTS FROM THE YERMAK PLATEAU (ARCTIC OCEAN, HOLE 911A) ${ }^{1}$
}

\author{
Jens Matthiessen² and Wolfram Brenner ${ }^{2}$
}

\begin{abstract}
Pliocene and Pleistocene sediments from Ocean Drilling Program Leg 151, Hole 911A, drilled on the innermost Yermak Plateau (Eastern Arctic Ocean), were studied for their dinoflagellate cyst content. Three assemblage zones were tentatively defined, characterized by the predominance of few species. The composition of the assemblages changed markedly, even within single assemblage zones, during the last 2.6 to $2.8 \mathrm{~m}$.y., reflecting the variable influence of warmer water from the Norwegian Sea, fluctuations in the influence of cold polar water masses, and the extent of sea-ice cover. Polar to subpolar surface water masses prevailed on the Yermak Plateau during the late Pliocene, when the eastern Arctic Ocean was probably isolated from the Norwegian-Greenland Sea. Intrusions of warmer water are recorded since the latest Pliocene, alternating with colder periods and a prolonged seasonal sea-ice cover. The composition of the dinoflagellate cyst assemblages has also changed considerably since the middle Pleistocene, reflecting the establishment of stronger fluctuations in surface water mass conditions than before at Yermak Plateau.
\end{abstract}

\section{INTRODUCTION}

The Yermak Plateau is a crucial location for reconstructions of the Arctic Ocean paleoceanography and paleoclimate. Today, the surface water masses are influenced by two contrasting current systems (Fig. 1). The West Spitsbergen Current (WSC), a branch of the Norwegian Atlantic Current (NAC), transports relatively warm water masses along the continental slope of the Barents Sea and Spitsbergen into the eastern Arctic Ocean (Aagaard, 1989; Aagaard et al., 1987; Bourke et al., 1988; Manley et al., 1992; Perkin and Lewis, 1984). The Norwegian Atlantic waters sink, due to cooling, on their way north below the polar water masses and circulate as the subsurface Atlantic layer along the shelf edge into the Arctic Ocean (e.g., Hunkins, 1990). Cold, less saline, Arctic surface water masses are exported from the Arctic Ocean with the Transpolar Drift and the East Greenland Current (EGC) into the Greenland Sea. These hydrographic conditions are reflected in the distribution of the seasonal sea-ice cover. In the short summer from June to September, open water may be found on the inner Yermak Plateau, while polar water masses with a dense sea-ice cover prevail during the rest of the year (e.g., Vinje, 1983).

During Ocean Drilling Program (ODP) Leg 151, Hole 911A was drilled on the Yermak Plateau at $80^{\circ} 28.5^{\prime} \mathrm{N}, 8^{\circ} 13.6^{\prime} \mathrm{E}$ in $902-\mathrm{m}$ water depth (Fig. 1). Initial shipboard paleomagnetic measurements and biostratigraphic studies on calcareous microfossils suggest that Hole 911A comprises a continuous upper Pliocene and Quaternary sedimentary sequence (Myhre, Thiede, Firth, et al., 1995). Shore-based investigations on calcareous microfossils reveals additional biostratigraphic datums, confirming high average sedimentation rates on the order of 9 to $17 \mathrm{~cm} / \mathrm{k} . \mathrm{y}$. during the last $\sim 2.8 \mathrm{~m}$.y. (Sato and Kameo, this volume; Spiegler, this volume). Therefore, Site 911 provides a high-resolution sedimentary sequence in the Arctic Ocean document-

Thiede, J., Myhre, A.M., Firth, J.V., Johnson, G.L., and Ruddiman, W.F. (Eds.), 1996. Proc. ODP, Sci. Results, 151: College Station, TX (Ocean Drilling Program).

${ }^{2}$ GEOMAR, Research Center for Marine Geosciences, University of Kiel, Wischhofstraße 1-3, Building 4, 24248 Kiel, Federal Republic of Germany.

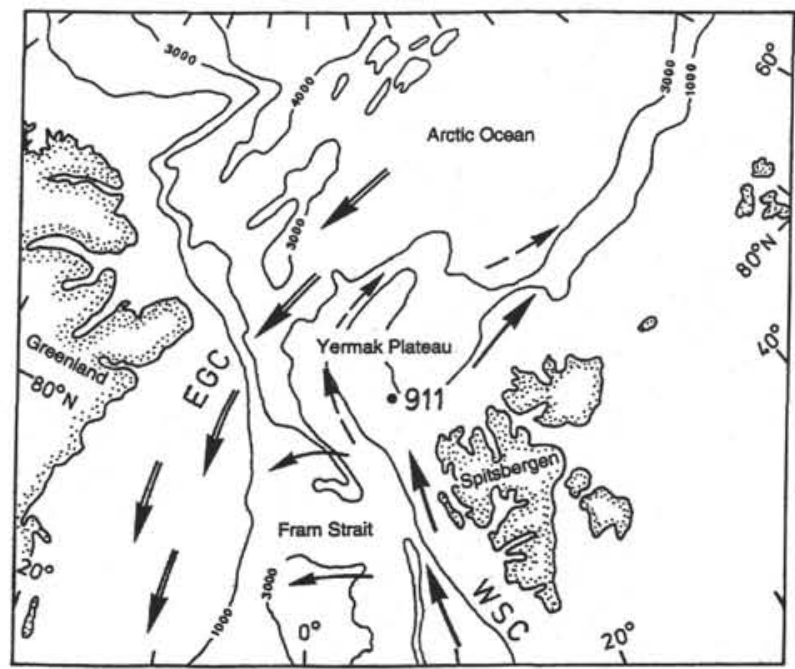

Figure 1. Location map of Site 911 and the schematic surface currents in the Fram Strait and the eastern Arctic Ocean (WSC = West Spitsbergen Current; EGC $=$ East Greenland Current). The broken lines indicate subsurface currents. Depth contours are in meters.

ing the climatic and paleoceanographic history since the onset of major Northern Hemisphere glaciations around 2.5 to $2.6 \mathrm{Ma}$.

The purpose of this initial study is:

1. to establish a basic dinoflagellate cyst ecostratigraphy;

2. to document the large-scale temporal changes in dinoflagellate cyst assemblage composition, which have occurred in response to changes in the influence of the West Spitsbergen Current and extension of polar water masses; and

3 . to compare the dinoflagellate cyst record with the paleoceanographic development in the Norwegian Sea and Arctic Ocean. 


\section{METHODS}

The sediments of Hole 911A were sampled at roughly 10-m intervals, representing one sample per core. Samples were freeze-dried and, after weighing, processed with cold $10 \% \mathrm{HCl}$ and cold $38 \%-$ $40 \% \mathrm{HF}$ to remove carbonates and silicates, respectively. The treatment with hydrofluoric acid was repeated until all silicates were dissolved. After each acid treatment, the organic matter was concentrated by wet sieving through $6-\mu \mathrm{m}$ polyester gauze. Neither heavy liquid separation nor oxidation with concentrated $\mathrm{HNO}_{3}$ or $\mathrm{HCl}$ were applied to prevent the selective loss of the more fragile dinoflagellate cysts or the separation of cysts filled with pyrite. Aliquots of the residues were mounted in glycerin gelatin. Dinoflagellate cyst concentrations were calculated using the method of Stockmarr (1971). Spore tablets were used containing Lycopodium spore (X $=12,542 ; \mathrm{S}=$ $\pm 2081 ; \mathrm{V}= \pm 3.3 \%$ ). One Lycopodium spore tablet was added to each sample during hydrochloric acid treatment.

Most samples, from the relatively well-dated uppermost Pliocene and Quaternary section down to 400 meters below seafloor (mbsf), were selected for an initial quantitative study; this represents a low temporal resolution of approximately 50,000 to 200,000 years. Variable numbers of Pliocene and Quaternary dinoflagellate cysts and acritarchs were counted because of the fluctuations in concentrations and the high content of other palynomorphs. Terrestrial palynomorphs (e.g., pollen and spores) usually dominate in samples, and reworked acritarchs and dinoflagellate cysts are rare. We attempted to count at least 100 specimens of Pliocene and Quaternary dinoflagellate cysts and acritarchs, which could be achieved with most samples.

The raw data are recorded in Table 1. Asterisks denote taxa which were found in additional strewn slides, but not counted. The category "dinocysts indeterminable" contains all autochthonous cysts that were not identified, partly because of poor preservation. Other organic-walled microfossils such as chlorophycean and prasinophycean algae are present to rare in most samples and will be described elsewhere. The percentage abundances of selected taxa from samples with counts above 80 dinoflagellate cysts are described in Figure 2.

\section{LITHOSTRATIGRAPHY AND CHRONOSTRATIGRAPHY}

A sequence of $\sim 500 \mathrm{~m}$ of homogeneous, very dark gray, clayey silts, and silty clays was recovered in Hole 911A. The sequence is divided into two lithologic units based on the variation in dropstone abundance, which is lower in Subunit IB than in IA (Myhre, Thiede, Firth, et al., 1995). Biogenic particles are rare in both units and calcium carbonate values rarely exceed $5 \%$. These sediments were deposited in a glaciomarine environment near and/or under the ice edge/ sea-ice cover. The boundary between both units was placed at $\sim 380$ mbsf.

The core recovery in Hole $911 \mathrm{~A}$ was $91.8 \%$. Therefore, the magnetostratigraphy provides an almost continuous time control for the upper $400 \mathrm{~m}$ of sediments spanning approximately the last 2.6 to 2.8 Ma (Myhre, Thiede, Firth, et al., 1995). Calcareous nannofossil datums, which were defined in the northeastern North Atlantic, refine the magnetostratigraphy in the Quaternary (Sato and Kameo, this volume) and the planktonic foraminifer biostratigraphy supports the chronostratigraphic framework (Spiegler, this volume).

The Pliocene/Quaternary boundary was defined from calcareous nannofossil and planktonic foraminifer evidence and is located above the Olduvai chron as in the type section in Italy (Hull et al., this volume). This is in conflict with Cande and Kent (1992), who placed it

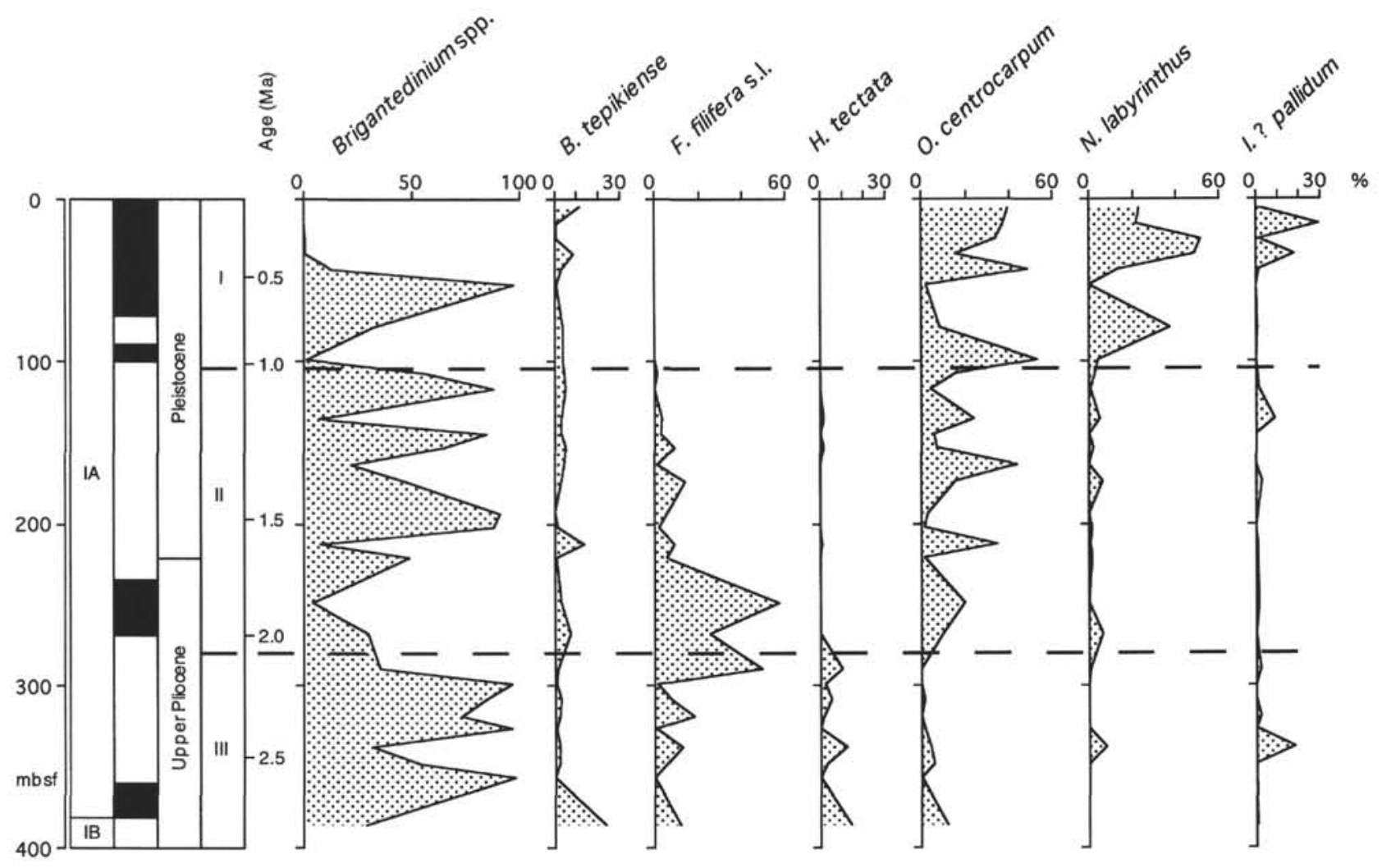

Figure 2. Correlation of lithostratigraphy, magnetostratigraphy, and chronostratigraphy (Myhre, Thiede, Firth, et al., 1995) with dinoflagellate cyst assemblage zones. The calculated ages are based on the dated boundaries of magnetostratigraphic chronozones. Selected dinoflagellate cyst taxa illustrate the major changes in the assemblage composition. 
Table 1. Dinoflagellate cysts and acritarchs in upper Pliocene and Pleistocene sediments from Hole 911A.

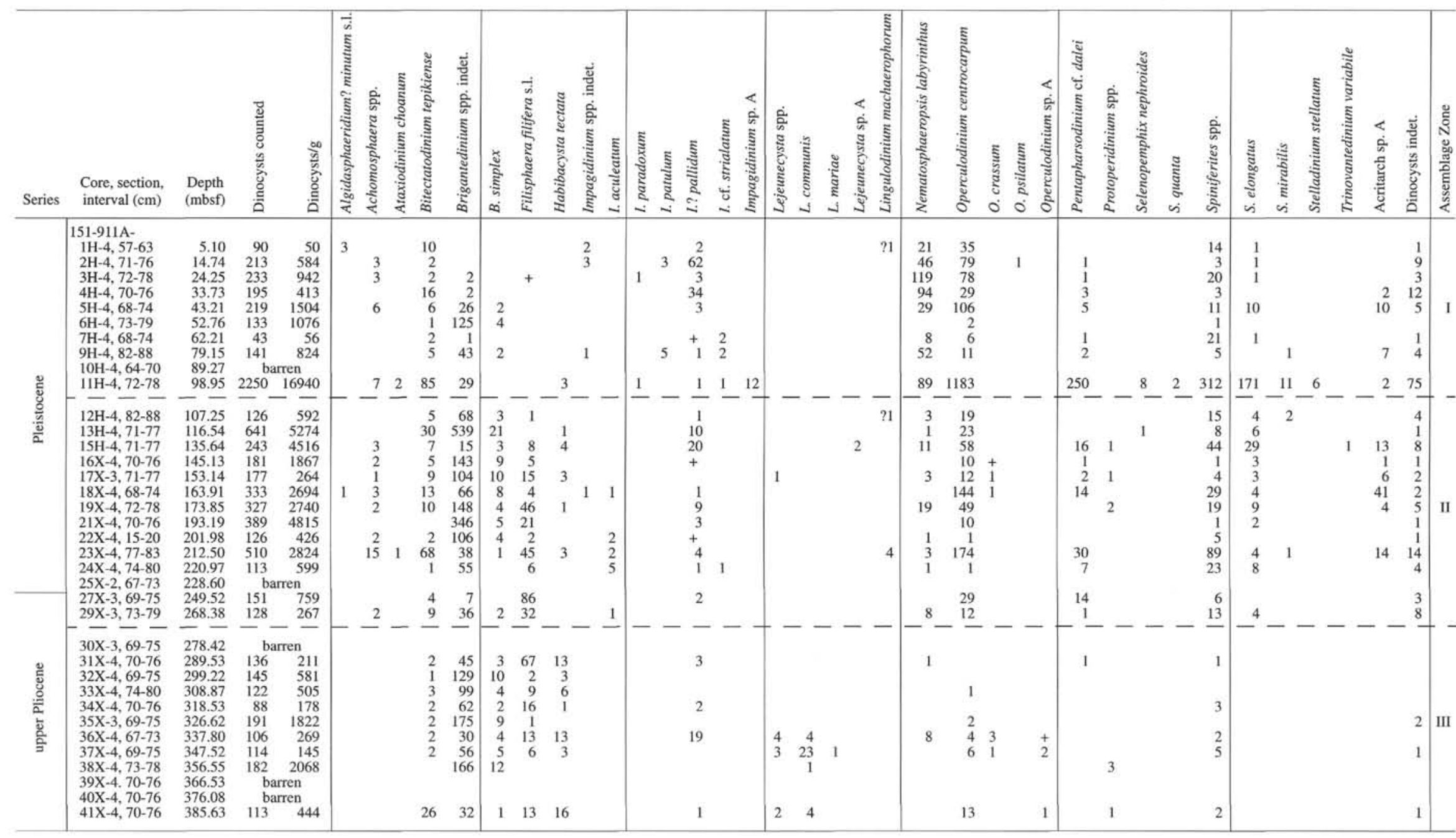

Note: Numbers indicate specimens counted (+ indicates species present, but not counted). 
in the Olduvai chron. Unfortunately, the lowermost $100 \mathrm{~m}$ of sediment can only be dated as undifferentiated upper Pliocene. Sedimentation rates are relatively high for an Arctic Ocean site, ranging between 9 and $17 \mathrm{~cm} / \mathrm{k} . \mathrm{y}$.

The chronostratigraphic framework established above is used to date the stratigraphic occurrence and distribution of the dinoflagellate cyst assemblages to avoid ambiguous circular arguments in comparison to other work.

\section{DINOFLAGELLATE CYST ECOSTRATIGRAPHY Dinoflagellate Cyst Assemblage Zones}

The dinoflagellate cyst record of Hole $911 \mathrm{~A}$ is characterized by fluctuations in the number of a few dominant species (Table 1, Fig. 2 ). The variability occurs both in the composition of assemblages and in dinoflagellate cyst concentrations. Cyst concentrations are not related to specific assemblages.

Biostratigraphic zonations based on dinoflagellate cysts were not established up to now for the late Pliocene and Quaternary in high latitudes because of the limited knowledge of their temporal and spatial distribution in these sediments (e.g., de Vernal et al., 1992). Stratigraphic ranges are known roughly for a few species. Habibacysta tectata and Filisphaera filifera s.l. might have some independent biostratigraphic value for age assignments in the Arctic Ocean. Both species became extinct in the lower to middle Pleistocene of the northern high latitudes (de Vernal et al., 1992; Head, 1993), which agrees with their last occurrences in Hole 911A in the middle Pleistocene.

Three assemblage zones are tentatively defined based on distinct changes in the composition of assemblages and abundance of individual species. Definite boundaries are not defined because changes in the assemblages occurred over relatively long stratigraphic intervals, because of a low sample density. The high variability in assemblage composition even within single assemblage zones suggests that the zones might be further subdivided if more samples were analyzed.

\section{Assemblage Zone I}

Samples $151-911 \mathrm{~A}-1 \mathrm{H}-4,57-63 \mathrm{~cm}$, to $11 \mathrm{H}-4,72-78 \mathrm{~cm}$, approximately $0-103 \mathrm{mbsf}$, are middle to lower Pleistocene.

The composition of assemblages is highly variable, but it is characterized by changes in dominance between Operculodinium centrocarpum and Nematosphaeropsis labyrinthus (Fig. 2). N. labyrinthus is common to abundant only in Zone I. Bitectatodinium tepikiense, Brigantedinium spp., Impagidinium? pallidum and Spiniferites spp. are additionally important in some samples in this zone. Impagidinium patulum, Impagidinium paradoxum, and Impagidinium sp. A are present only in Zone I. The transition to Zone II is marked by the uphole increase in percentage abundance of $N$. labyrinthus and $O$. centrocarpum, and the approximate last occurrences of Filisphaera filifera s.1. and Habibacysta tectata.

\section{Assemblage Zone II}

Samples $151-911 \mathrm{~A}-12 \mathrm{H}-4,82-88 \mathrm{~cm}$, to $29 \mathrm{X}-3,73-79 \mathrm{~cm}$, approximately 103-279 mbsf, are lower Pleistocene to uppermost Pliocene.

Percentage abundances of Brigantedinium spp. and $O$. centrocarpum have an approximate reciprocal relationship (Fig. 2). Brigantedinium spp. is abundant to dominant in most samples from 103 to 203 mbsf, while $F$. filifera s.I. increases in percentage abundance downcore and characterizes assemblages at the base of this assemblage zone. $N$. labyrinthus is always rare and Impagidinium aculeatum is confined to Zone II. Achomosphaera spp., species of Impagidinium except $I$. ? pallidum, Pentapharsodinium cf. dalei, and Spiniferites elongatus occur approximately down to the base of Zone II. The transition to assemblage Zone III is marked by a distinct downhole decrease of $O$. centrocarpum, an acme occurrence of $F$. filifera s.l. and the downhole increase of Brigantedinium spp. and H. tectata.

\section{Assemblage Zone III}

Samples $151-911 \mathrm{~A}-31 \mathrm{X}-4,70-76 \mathrm{~cm}$, to $41 \mathrm{X}-4,70-76 \mathrm{~cm}$, approximately 279-386 mbsf, are upper Pliocene.

Zone III is characterized by a low number of taxa in most samples. Brigantedinium spp. is the dominant element in this zone (Fig. 2). B. tepikiense, $H$. tectata, and $F$. filifera s.I. are the only species that are almost persistently present. O. centrocarpum, $N$. labyrinthus, and Spiniferites spp. are present only in some samples in contrast to assemblages in Zones I and II. Lejeunecysta communis is rare to common in samples at the base of Zone III. Assemblages from the top of Zone III are transitional to assemblages in Zone II, because percentage abundances of $F$. filifera s.1. still are high.

\section{Paleoenvironmental Interpretation}

The strong fluctuations in assemblage composition, even within a single assemblage zone, indicate that environmental conditions changed considerably during the last 2.6 to $2.8 \mathrm{~m} . \mathrm{y}$. Although the ecological preferences of most dinoflagellate cyst species are not known in detail, the distribution pattern of individual species in surface sediments from the North Atlantic, the Norwegian-Greenland Sea and the Eastern Arctic Ocean (Harland, 1983; Mudie, 1992; de Vernal et al., 1994; Matthiessen, 1995) can be used to interpret their occurrence in sediments from Site 911 . The composition of recent assemblages from the Norwegian-Greenland Sea and eastern Arctic Ocean is influenced either by the cold, relatively low-saline polar water masses of the Transpolar Drift and the EGC, or the relatively warmer, higher saline cold-temperate water masses of the NAC and WSC currents. Sediments underlying the polar to subpolar water masses are characterized by low diversity assemblages and taxa such as Brigantedinium spp. (mainly Brigantedinium simplex), Algidasphaeridium? minutum s.l., and $I$.? pallidum, whereas assemblages from cold-temperate water masses have a higher diversity and contain, among other species, $O$. centrocarpum, $N$. labyrinthus, and Spiniferites spp. (Harland, 1983; Mudie, 1992; Matthiessen, 1995). This principal distribution pattern can also be seen in Pliocene and Pleistocene sediments from Hole 911 (Table 1, Fig. 2). Brigantedinium spp. is present in most assemblages and dominates in almost half of the samples analyzed from Hole 911A. O. centrocarpum and $N$. labyrinthus characterize assemblages that generally have a high diversity.

However, it must be kept in mind that dinoflagellate cysts may be transported with surface currents and sediments over considerable distances (Dale, 1992; Dale and Dale, 1992; Matthiessen, 1995). Species that prefer warmer water masses can be advected from the Norwegian Sea with the WSC into the Arctic Ocean. Dinoflagellate cysts may also be transported from coastal environments of Spitsbergen to Site 911 . Therefore, the dinoflagellate cyst record of Site 911 reflects not only local surface water mass conditions, but also regional changes in the WSC and NAC currents. Thus, only changes in the abundance of taxa that are common to abundant in most samples are used to interpret the paleoenvironmental development (Fig. 2).

\section{Assemblage Zone III}

Dinoflagellate cyst assemblages that are dominated by spherical brown protoperidinioid cysts are known from different environments (e.g., Wall et al., 1977; Dale, 1985; Mudie, 1992; de Vernal et al., 1994; Matthiessen, 1995). Most protoperidinioid species probably 
are cysts of heterotrophic dinoflagellates, indicating that not only hydrographic conditions influence the occurrence and distribution of individual species, but also nutrients or the availability of food organisms. It is difficult to differentiate the environments by means of Brigantedinium species because most specimens cannot usually be identified to species level. Therefore, the composition of the entire assemblage must be used to characterize paleoenvironments.

There are two major types of assemblages that are dominated by Brigantedinium spp. Polar to subpolar environments are characterized by assemblages of low diversity, which are heavily dominated by Brigantedinium spp., often associated with Algidasphaeridium? minutum (e.g., Dale, 1985; Mudie, 1992; de Vernal et al., 1994; Rochon and de Vernal, 1994; Matthiessen, 1995). B. simplex is usually abundant to dominant in such assemblages (Mudie, 1992; Matthiessen, 1995). Additionally, B. cariacoense may be found (de Vernal et al., 1994; Rochon and de Vernal, 1994). B. simplex is considered an indicator of polar to subpolar conditions and sea ice, but the occurrence may also be associated with higher nutrient levels supplied from melting sea ice (Dale and Fjellså, 1994). This assemblage characterizes environments with variable sea-surface temperatures and reduced sea-surface salinities (somewhat below 33\%o) in summer and a relatively long seasonal sea-ice cover (e.g., de Vernal et al., 1994; Rochon and de Vernal, 1994; Matthiessen, 1995). Other protoperidinioid species are usually absent or extremely rare. Among gonyaulacoid species, which are regularly found in low abundances, are $O$. centrocarpum, $S$. elongatus, and $P$. cf. dalei.

Assemblages that are dominated by Brigantedinium spp. are also common in temperate regions. In particular, assemblages from coastal upwelling regions are heavily dominated by Brigantedinium spp. (e.g., Wall et al., 1977; Dale and Fjellså, 1994). These assemblages differ from polar to subpolar assemblages in having a high diversity, especially of protoperidinioid cysts. Even if most spherical brown protoperidinioid cysts can not be identified to species level, species such as Brigantedinium cariacoense, and cysts of Protoperidinium americanum, $P$. denticulatum, and $P$. punctulatum are present (e.g., Reid, 1977, Wall et al., 1977). In addition, several other protoperidinioid species of the genera Lejeunecysta and Selenopemphix, gymnodinioid, and gonyaulacoid species may be found.

Although only low proportions of Brigantedinium spp. could be assigned to B. simplex (Table 1), sparse occurrences of other protoperidinioid species in most samples, which comprise more than $60 \%$ to $80 \%$ Brigantedinium spp., and the low diversity of these assemblages suggests harsh environmental conditions. The low percentage abundances of gonyaulacoid species such as Spiniferites spp., O. centrocarpum, and $N$. labyrinthus, which prefer relatively warmer conditions (e.g., Harland, 1983; Mudie, 1992; Matthiessen, 1995), support an interpretation of a cold ice-covered environment. Sea-surface temperatures must have been low and salinities were somewhat reduced. The eastern Arctic Ocean was probably covered by sea ice most of the year.

$B$. tepikiense, $F$. filifera s.l., and $H$. tectata all have a conspicuous cyst wall and are the second important group in assemblage Zone III. The ecologic preferences of the extinct $F$. filifera s.l. and $H$. tectata, which are important in samples with low percentage abundances of Brigantedinium spp., are not known. F. filifera s.l. only occurs in northern high latitudes (de Vernal et al., 1992; Head, 1993). It is common in Pliocene sediments from the Arctic Ocean (Mudie et al., 1990), suggesting that it is adapted to cooler conditions. H. tectata probably tolerates cool temperate to subtropical or tropical conditions, but it apparently prefers cooler conditions (Head, 1994). Both species co-occur with the extant species B. tepikiense. High percentage abundances of $B$. tepikiense are attributed to the more offshore mixing of polar front influenced oceanic waters with cold, brackish meltwaters from ice (Dale, 1985; Bakken and Dale, 1986; Andersen et al., 1991). In the northwestern Atlantic, B. tepikiense probably prefers environments that experience a strong seasonality with cold win- ter and warm summer sea-surface temperatures (de Vernal et al. 1994). It is associated with salinities around $30 \%$, and a relatively short seasonal sea-ice cover or even ice-free conditions. Assemblages containing higher abundances of B. tepikiense, $H$. tectata, and F. filifera s.l. probably indicate somewhat warmer summer conditions, and a shorter period of seasonal sea-ice cover, compared to assemblages dominated by Brigantedinium spp. Assemblages that additionally contain $I$.? pallidum, $N$. labyrinthus, $O$. centrocarpum, and Lejeunecysta spp. indicate less harsh conditions. I.? pallidum is associated with polar to subpolar conditions (Dale and Dale, 1992; Matthiessen, 1995), whereas $N$. labyrinthus and $O$. centrocarpum, prefer cold-temperate conditions.

The assemblages in Zone III document a predominant influence of cool to cold conditions with possible fluctuations of sea-surface temperatures and salinities in summer, and in the length of the seasonal ice cover. Variable abundances of species preferring relatively warmer conditions suggest that the influence of the WSC changed considerably, being low or almost absent for some time. Therefore, the circulation systems of the Arctic Ocean and the NorwegianGreenland Sea may have been episodically decoupled between $\sim 2.7$ and 2.1 Ma.

\section{Assemblage Zone II}

The marked increase in abundance of species which prefer relatively warmer conditions such as $N$. labyrinthus, $O$. centrocarpum, and species of Spiniferites spp. (e.g., Harland, 1983; Mudie, 1992; Matthiessen, 1995) suggests that the inflow of relatively warmer water increased around 2.1 to $2.0 \mathrm{Ma}$. O. centrocarpum is an ubiquitous species, tolerating a wide range of temperature and salinity conditions, and seasonal extent of sea-ice cover (e.g., Wall et al., 1977; Harland, 1983; Dale, 1985; de Vernal et al., 1994). This species is abundant to dominant in recent sediments from the Norwegian Sea (Harland, 1983; Matthiessen, 1995). P. cf. dale, which is common in some samples in Hole 911A, generally co-occurs with $O$. centrocarpum in Hole 911 A. It is abundant in regions characterized by sea-surface temperatures close to the freezing point in winter, variable seasurface temperatures in summer, and a relatively long seasonal seaice cover (de Vernal et al., 1994). This species is also associated with reduced summer sea-surface salinities below 30\% (Dale, 1976; de Vernal et al., 1994). The paleoecological significance of the peak abundance of $F$. filifera s.l. at the base of Zone II is not understood. The presence of $B$. tepikiense, $N$. labyrinthus, $O$. centrocarpum, and Spiniferites spp. suggests that a warming occurred at the base of Zone II and cold-temperate conditions were established for some time in the late Pliocene. The assemblages that are characterized by high abundances of $O$. centrocarpum and $F$. filifera s.l. alternate with assemblages of lower diversity, dominated by Brigantedinium spp. These assemblages are similar to assemblages from the upper part of Zone III, and indicate polar to subpolar conditions.

The composition of the assemblages in Zone II suggests stronger fluctuations in the surface water conditions since 2.1 to $2.0 \mathrm{Ma}$. Perhaps colder conditions with reduced sea-surface salinities, and a longer seasonal sea-ice cover changed with more open conditions in summer and an increased influence of relatively warmer, higher saline water from the WSC.

\section{Assemblage Zone I}

Since $\sim 1$ Ma the dinoflagellate cyst assemblages show a similarity in composition to Holocene assemblages from oceanic surface water environments in the Norwegian-Greenland Sea and Eastern Arctic Ocean (Harland, 1983; Mudie, 1992; Matthiessen, 1995). Changes in abundance between $O$. centrocarpum and $N$. labyrinthus are known from upper Quaternary sediments of the Norwegian-Greenland Sea and the North Atlantic Ocean, but the ecological significance is not 
understood (Matthiessen, 1991; Harland, 1994; Rochon and de Vernal, 1994). $N$. labyrinthus has similar ecological requirements as $O$. centrocarpum. The predominance of $O$. centrocarpum and $N$. labyrinthus indicates that the influence of the NAC and WSC on the water masses at Yermak Plateau increased episodically since the middle Pleistocene.

High-percentage abundances of $I$.? pallidum and Brigantedinium spp. in a few samples indicate that there were fluctuations at times toward colder conditions. I.? pallidum has a wide distribution in the Greenland and Iceland seas and Eastern Arctic Ocean and is, in contrast to other species of Impagidinium, a distinct indicator of polar to subpolar water masses (Dale and Dale, 1992; Mudie, 1992; Matthiessen, 1995). A complete return to polar conditions is recorded only in Sample 151-911A-6H-4, 73-79 cm, but this pattern may be affected by the large sampling intervals.

The composition of assemblages is more variable than in the preceding zones, suggesting enhanced fluctuations in the surface water conditions. The contrasting environmental conditions appear to resemble the modern situation in the Norwegian-Greenland Sea and the eastern Arctic Ocean. Probably, a similar circulation system was established during the past $1.0 \mathrm{Ma}$, which might account for the last occurrences of $F$. filifera s.l. and $H$. tectata in Hole 911A. The inflow of the WSC fluctuated, being stronger when I. patulum and I. paradoxum were present. The seasonal sea-ice cover must have varied considerably and extended onto the Yermak Plateau, when $1 . ?$ pallidum and Brigantedinium spp. were more abundant.

\section{PLIOCENE AND PLEISTOCENE SURFACE WATER MASSES IN THE ARCTIC OCEAN AND NORWEGIAN SEA}

\section{Paleoceanographic Evolution of the Norwegian Sea}

The interpretations derived from the dinoflagellate cyst record of Hole $911 \mathrm{~A}$ confirm the profound influence of the North Atlantic/ Norwegian Sea currents on the surface water masses of the eastern Arctic Ocean. The holes drilled during ODP Leg 104 in the Norwegian Sea (Eldholm, Thiede, Taylor, et al., 1989) are the major reference sites for unraveling the Neogene paleoceanography of the eastern Arctic Ocean. This is because they are located in the path of the Norwegian Atlantic Current, which transports relatively warm water masses from the northeastern North Atlantic into the Eastern Arctic Ocean.

Sedimentological, micropaleontological, stable oxygen, and carbon isotope investigations reveal detailed reconstructions of the development of surface water masses and ice sheets in Scandinavia in the past 2.8 to 2.6 m.y. (e.g., Jansen et al., 1988; Henrich and Baumann, 1994). Ice caps were small over Scandinavia between 2.6 and 1.0 Ma, and moderate glacial conditions prevailed in the Norwegian Sea with periods of weak influence of Atlantic water into the eastern Norwegian Sea. After $1 \mathrm{Ma}$, contrasts between glacials and interglacials increased, caused by stronger glaciations on Scandinavia and an increase in strength of the Norwegian Current during interglacials. The last 0.6 m.y. are characterized by an increased meridionality and stronger Norwegian Current intrusions and strong glaciations on the surrounding land masses.

Although the temporal resolution of the records from the Norwegian Sea and Yermak Plateau are different, the chronology of paleoceanographic events is similar. An interval with sporadic occurrences of both planktonic foraminifers and calcareous nannofossils in Hole 644A from the Norwegian Sea between $\sim 2.6$ and 1.9 Ma (Henrich and Baumann, 1994) corresponds to assemblages in Zone III on Yermak Plateau, which indicate predominately polar surface-water conditions with an extended seasonal sea-ice cover. This feature appears to be puzzling, but it has been observed previously that often distinct dinoflagellate cyst assemblages are to be found in glacial se- quences (e.g., the Weichselian described in Bakken and Dale, 1986; Andersen et al., 1991) which are barren of other planktonic microfossils. Comparisons of the distribution patterns in modern sediments from the Greenland Sea suggest that both biotic (low production) and abiotic processes (e.g., dissolution) may account for the sporadic occurrences of calcareous and siliceous planktonic microfossils in polar to subpolar environments, where dinoflagellate cysts are still present in the sediments (Samtleben et al., 1995).

Episodic inflow of Atlantic water into the eastern Arctic Ocean occurred in the period between 2.1 and $1.0 \mathrm{Ma}$, but it is not yet possible to correlate accurately specific events in the Norwegian Sea with events in the Yermak Plateau record. Relatively high abundances of coccoliths have been recognized at Site 644 in certain intervals between 1.9 and 1.3 Ma suggesting short-term intrusions of Atlantic water (Henrich and Baumann, 1994). The last $1 \mathrm{~m} . \mathrm{y}$. are characterized by strong fluctuations in abundances of planktonic foraminifers and coccoliths in the Norwegian Sea (Henrich and Baumann, 1994), and enhanced fluctuations in the composition of dinoflagellate cyst assemblages on Yermak Plateau. The low sampling resolution at Site 911 does not allow the recognition of glacial/interglacial cycles that are reflected in the detailed calcareous microfossil records from the Norwegian Sea (Henrich and Baumann, 1994).

\section{Arctic Ocean Paleoceanographic Records}

The late Pliocene and Pleistocene paleoceanography of the Arctic Ocean is a matter of intense debate. Because of the restricted number of available tracers and the rarity or absence of most planktonic microfossil groups, partly contradictory scenarios have been suggested for the paleoenvironmental development and for the occurrence and variability of the sea-ice cover (e.g., Aksu et al., 1988; Herman et al., 1989; Scott et al., 1989; Clark, 1990a, 1990b; Clark et al., 1990).

Additionally, the comparison with the dinoflagellate cyst record of Site 911 is hampered by the limited stratigraphic control and differences in the temporal resolution. Sedimentation rates are at least one order of magnitude lower in the central Arctic Ocean than on Yermak Plateau, and stratigraphic control is based usually on magnetostratigraphic and palynological data (e.g., Aksu and Mudie, 1985; Clark, 1990a, 1990b; Herman et al., 1989). Therefore, age assignments and interpretations of major paleoenvironmental changes in the Arctic Ocean differ somewhat even if the sites are close to each other. Any correlation of events from the central Arctic Ocean with Site 911 is further complicated because the Yermak Plateau is close to the margin of the Arctic pack ice that experiences strong seasonal and interannual fluctuations. However, major events, such as fluctuations in the inflow of relatively warmer water, should influence the central Arctic Ocean as well.

Paleoceanographic changes in the marginal areas of the Arctic Ocean have been inferred from the occurrence and distribution of ostracodes in marine sediments exposed on the surrounding land masses. Cronin et al. (1993) show that summers were ice-free in the margins of the Arctic Ocean in some years between 3.5 and $2.0 \mathrm{Ma}$, explaining this by suggesting that North Atlantic water, which was warmer than today's, flowed into the Arctic Ocean. This is, at first glance, at variance with the reconstruction of cold surface water conditions and an extended ice cover on Yermak Plateau between 2.7 and $2.1 \mathrm{Ma}$, that is based on the dinoflagellate cyst record of Site 911 . However, Cronin et al. (1993) note that most coastal exposures in the Arctic Ocean region represent interglacial deposits, and paleotemperature estimates derived from the ostracodes do not apply to glacial periods.

The Pliocene and Pleistocene sequences of the central Arctic Ocean are characterized by marked changes in occurrence and abundances of calcareous microfossils, documenting marked fluctuations in the environment. The major paleoceanographic events may have occurred synchronously in the entire Arctic Ocean. Dinoflagellate 
cyst analysis of Pliocene and Pleistocene sediments from Alpha Ridge revealed changes in the stratigraphic distribution of individual species (Mudie et al., 1990), which appear to be almost synchronous with the major change at Yermak Plateau.

At $\sim 2.7-2.1 \mathrm{Ma}$, a long period of increased length of seasonal seaice cover occurred on the Yermak Plateau. This is almost coeval with the first maximum of calcareous benthic and planktonic foraminifer assemblages in a sediment core from Alpha Ridge, providing the first evidence of perennial ice cover between $\sim 2.6$ and $2.2 \mathrm{Ma}$ (Aksu et al., 1988; Scott et al., 1989).

The marked change in surface water conditions after $2.1 \mathrm{Ma}$ at Yermak Plateau probably occurred simultaneously with the increase in calcareous dinoflagellate cysts and planktonic foraminifers, and the permanent change in benthic foraminiferal assemblages from agglutinated to calcareous species in the western Arctic Ocean (Aksu et al., 1988; Herman et al., 1989; Scott et al., 1989; Clark et al., 1990). The age assignments are somewhat contradictory, ranging from 2.5 $\mathrm{Ma}$ (Herman et al., 1989), 2.0 to $1.5 \mathrm{Ma}$ (Clark et al., 1990), to later than 1.8 Ma (Aksu et al., 1988; Scott et al., 1989). Clark et al. (1990) suggest that the WSC penetrated for the first time into the Arctic Ocean. These intrusions of warmer water must have altered with periodic continuous sea-ice cover (Scott et al., 1989). This agrees with the dinoflagellate cyst record from Yermak Plateau which indicates changes between cold, ice-covered conditions and the influence of relatively warmer water.

Planktonic foraminifers increased in abundance and calcareous dinoflagellate cysts disappeared between 0.9 and $0.8 \mathrm{Ma}$ (Aksu et al., 1988; Herman et al., 1989; Clark et al., 1990). This event is attributed to the onset of perennial sea-ice cover in some central Arctic Ocean records (Herman et al., 1989), but peaks in planktonic foraminifer abundances are attributed to interglacials punctuating the long periods of permanent ice cover during the glacials, at least along the margins (Poore et al., 1993). Such cycles are not clearly seen at Site 911. Cold-temperate assemblages alternate with subpolar to polar assemblages, although the sampling intervals are too large to resolve glacial/interglacial cycles in detail.

\section{CONCLUSIONS}

Dinoflagellate cyst analysis of Pliocene and Pleistocene sediments from Site 911 revealed a distinct succession of assemblages, which allowed us to establish an ecostratigraphic zonation. Changes in assemblage composition can be interpreted to reflect major paleoceanographic events in the eastern Arctic Ocean since the late Pliocene. The surface water masses on Yermak Plateau were characterized by predominantly polar conditions with an extended sea-ice cover between 2.7 and 2.1 Ma. After $2.1 \mathrm{Ma}$, intrusions of relatively warmer water occurred on the Yermak Plateau. The strength of inflow fluctuated such that colder conditions, with extended length of seasonal sea-ice cover, prevailed temporarily. Since $\sim 1.0 \mathrm{Ma}$, the dinoflagellate cyst assemblage composition varied sufficiently to suggest that glacial/interglacial cycles may have played a major role in the Yermak Plateau paleoceanography.

Despite difficulties with the temporal resolution in records from the Norwegian Sea and Yermak Plateau, major paleoceanographic events were probably coeval in the NAC/WSC current system during the past $\sim 2.8 \mathrm{Ma}$. Correlation to paleoceanographic events in the central Arctic Ocean may be possible, but is presently tentative because of differences in temporal resolution and contradictory reconstructions of the Neogene Arctic Ocean paleoceanography.

\section{SYSTEMATICS}

Taxonomy follows that of Lentin and Williams (1993), unless stated otherwise below.

\author{
Division DINOFLAGELLATA (Bütschli, 1885) Fensome et al., 1993 \\ Class DINOPHYCEAE Pascher, 1914 \\ Subclass GYMNODINIPHYCIDAE Fensome et al., 1993 \\ Order GYMNODINIALES Apstein, 1909 \\ Family GYMNODINIACEAE (Bergh, 1881) Lankester, 1885
}

Genus ALGIDASPHAERIDIUM Matsuoka and Bujak, 1988

Algidasphaeridium? minutum s.1. (Reid and Harland in Harland et al., 1980) Matsuoka and Bujak 1988

Remarks: This taxon includes morphotypes that resemble A.? minutum, but show some variability in process morphology (cf. de Vernal et al., 1992; Mudie, 1992; Matthiessen, 1991, 1995).

\author{
Subclass PERIDINIPHYCIDAE Fensome et al., 1993 \\ Order GONYAULACALES Taylor, 1980 \\ Family GONYAULACACEAE Lindemann, 1928
}

Genus ACHOMOSPHAERA Evitt, 1963

Achomosphaera spp.

Remarks: Includes Achomosphaera andalousiensis Jan du Chêne, 1977, Achomosphaera ramulifera (Deflandre, 1937) Evitt, 1963, and specimens that could not be identified to species level.

\section{Genus BITECTATODINIUM Wilson, 1973}

Bitectatodinium tepikiense Wilson, 1973

$$
\text { (Pl. 1, Figs. 6, 7) }
$$

Remarks: B. tepikiense differs from Habibacysta tectata Head et al., 1989 in having a $2 \mathrm{P}$ archeopyle with well-defined angles and a luxuria that consists of a complex arrangement of lamellae that are perpendicular or subperpendicular to the pedium (Head, 1994). The lamellae are often thickened and subcircular at the base and differ from those on $\mathrm{H}$. tectata by having a larger diameter, a denser distribution, and a tendency to be fused with adjacent bases. $B$. tepikiense has no tegillum and in contrast to $F$. filifera has a periphragm that lacks a complete reticulate or microreticulate structure (Head, 1993). Individual specimens that could not be clearly identified by showing a $2 \mathrm{P}$ archeopyle were studied with phase contrast at $1000 \times$ magnification.

\section{Genus FILISPHAERA (Bujak, 1984) Head, 1993 \\ Filisphaera filifera s.l. (Bujak, 1984) Head, 1993 (Pl. 1, Figs. 3, 4)}

Remarks: Recently, Head (1993) emended $F$. filifera and erected two subspecies, distinguished by small differences in the height of the periphragmal septa. Because these features are at the lower limit of the resolution of a light microscope $(\sim 1-2 \mu \mathrm{m})$ and are difficult to measure when counting at $400 \times$ magnification (ocular scale bar $\sim 2.5 \mu \mathrm{m}$ ), these subspecies were not differentiated. F. microornata (Head et al., 1989) Head, 1993 may also be included in $F$. filifera s.I. because the small differences in diameter of the microreticulation, which allows the differentiation of these species, are difficult to discern during routine counting.

F. filifera differs principally from $H$. tectata Head et al., 1989 (PI. 1, Figs. $1,2)$ in having a luxuria composed of radiating septa that form a distally open microreticulum, while $H$. tectata has a luxuria which terminates distally as tegillum (Head, 1994). Phase contrast was used in combination with interference contrast to distinguish both of the species.

\section{Genus IMPAGIDINIUM Stover and Evitt, 1978}

$$
\text { Impagidinium spp. }
$$

Remarks: Includes specimens that cannot be unequivocally assigned to a certain species.

$$
\text { Impagidinium cf. strialatum (Wall, 1967) Stover and Evitt, } 1978
$$

Remarks: Differs slightly from $I$. strialatum in having slightly larger sutural septa and in lacking the weak radial striation on the sutural septa. 


$$
\text { Impagidinium sp. A }
$$

Remarks: Specimens that resemble Impagidinium japonicum Matsuoka 1983 are counted as Impagidinium sp. A.

$$
\text { Genus OPERCULODINIUM Wall, } 1967
$$

Operculodinium centrocarpum (Deflandre and Cookson, 1955) Wall, 1967 (Pl. 1, Fig. 12)

Remarks: The assignment of Pliocene and Quaternary dinoflagellate cysts to $O$. centrocarpum is discussed after the reexamination of the Miocene type material (see Head, 1993). The species $O$. centrocarpum comprises a large variety of morphotypes, and specimens from Pliocene and Pleistocene sediments of Yermak Plateau are similar to specimens attributed by Wall (1965) and Wall and Dale (1968) to $O$. centrocarpum. Most specimens from Yermak Plateau have well-developed processes (PI. 1, Fig. 12).

$$
\text { Operculodinium crassum Harland, } 1979
$$

Remarks: Operculodinium crassum is probably a taxonomic junior synonym of $O$. israelianum (see Head and Wrenn, 1992).

\section{Operculodinium sp. A}

Remarks: The observed specimens are similar to Operculodinium ?eirikianum Head et al. 1989, but the bad preservation does not allow an unequivocal identification.

$$
\text { Genus SPINIFERITES Mantell, } 1850
$$

Spiniferites elongatus Reid, 1977

(PI. 1, Fig. 9)

Remarks: This taxon includes $S$. elongatus and morphotypes that intergrade between S. elongatus and S. frigidus Harland and Reid in Harland et al., 1980. However, the typical $S$. frigidus morphotype was not found.

$$
\text { Spiniferites spp. indet. }
$$

Remarks: Species other than S. elongatus and Spiniferites mirabilis (Rossignol, 1964) Sarjeant, 1970 are grouped here because preservation and the orientation of specimens prevented identification to species level.

$$
\text { Order PERIDINIALES Haeckel } 1894
$$$$
\text { Family CONGRUENTIDIACEAE Schiller } 1935
$$

\section{Genus BRIGANTEDINIUM Reid 1977}

Brigantedinium spp. indet.

Remarks: All spherical brown protoperidinioid cysts are counted as Brigantedinium spp. indet. A larger number of specimens could be only assigned to B. simplex (Wall, 1965) Reid, 1977 (Pl. 1, Fig. 5), whereas only a single specimen of B. cariacoense (Wall 1967) Reid 1977 has been found. B. simplex is listed separately in Table 1 because it is the only species of Brigantedinium preferring polar to subpolar conditions (Dale, 1985; Mudie 1992; Matthiessen, 1995).

\section{Genus LEJEUNECYSTA Artzner and Dörhöfer, 1978}

$$
\text { Lejeunecysta spp. }
$$

Remarks: Specimens of Lejeunecysta that cannot be differentiated are assigned to Lejeunecysta spp.

\section{Genus PROTOPERIDINIUM Bergh, 1881}

\section{Protoperidinium spp.}

Remarks: This taxon comprises different morphotypes of protoperidinioid affinity with a large variability in process morphology.

$$
\text { Family PERIDINIACEAE Ehrenberg } 1831
$$

\section{Genus PENTAPHARSODINIUM Indelicato and Loeblich, 1986}

$$
\begin{aligned}
& \text { Pentapharsodinium cf. dalei Indelicato and Loeblich, } 1986 \\
& \text { (PI. 1, Fig. 10) }
\end{aligned}
$$

Remarks: The process morphology on $P$. cf. dalei is highly variable as it is known from recent cysts (cf. Dale, 1977), but processes of Pleistocene and Pliocene specimens are slightly larger and more strongly developed than on recent morphotypes.

$$
\text { Incertae sedis }
$$

Group Acritarcha Evitt, 1963

Acritarch sp. A

(Pl. 1, Fig. 8)

Remarks: Acritarch sp. A superficially resembles $P$. dalei, but differs in having numerous, equally distributed processes of similar shape. Processes are sometimes fenestrate at the base and are minutely papillate.

\section{ACKNOWLEDGMENTS}

We thank Anne de Vernal, Rex Harland, and John Firth who thoroughly reviewed the manuscript and provided many helpful comments. Critical reading of the manuscript by W.R. Ruddiman is acknowledged. We thank A. Blum for technical assistance in the laboratory. This study was supported by a grant from the Deutsche Forschungsgemeinschaft.

\section{REFERENCES}

Aagaard, K., 1989. A synthesis of the Arctic Ocean circulation. Rapp. P.-V. Réun. Cons. Int. Explor. Mer, 188:11-22.

Aagaard, K., Foldvik, A., and Hillman, S.R., 1987. The West Spitsbergen current: disposition and water mass transformation. J. Geophys. Res., 92:3778-3784.

Aksu, A.E., and Mudie, P.J., 1985. Magnetostratigraphy and palynology demonstrate at least 4 million years of Arctic Ocean sedimentation. Nature, 318:280-283.

Aksu, A.E., Mudie, P.J., Macko, S.A., and de Vernal, A., 1988. Upper Cenozoic history of the Labrador Sea, Baffin Bay, and the Arctic Ocean: a paleoclimatic and paleoceanographic summary. Paleoceanography, 3:519-538.

Andersen, B.G., Bakken, K., Dale, B., Fugelli, E., Henningsmoen, K.E., Høeg, H.I., Nagy, J., Read, A., and Tellemann, H., 1991. Weichselian stratigraphy at Oppstad, Høgemork and Foss-Eigeland, Jæren, SW Norway. In Andersen, B.G., and Königsson, L.K. (Eds.), Late Quaternary Stratigraphy in the Nordic Countries 150,000-15,000 B.P. Uppsala, 109124.

Apstein, C., 1909. Die Pyrocysteen der Plankton-Expedition. In Hensen, V. (Ed.), Ergebnisse der Plankton-Expedition der Humboldt-Stiftung: Kiel (Lipsius and Tischer), 4.

Artzner, D.G., and Dörhöfer, G., 1978. Taxonomic note: Lejeunecysta nom. nov. Lejeunia Gerlach 1961 emend. Lentin and Williams 1976dinoflagellate cyst genus. Can. J. Bot., 56:1381-1382.

Bakken, K., and Dale, B., 1986. Dinoflagellate cysts in Upper Quaternary sediments from southwestern Norway and potential correlations with the oceanic record. Boreas, 15:185-190.

Bergh, R.S., 1881. Bidrag til Cilioflagellaternes Naturhistorie. Forelobige meddelelser. Dansk Naturhist. For. Kjobenhavn, Vid. Medd., Ser. 4, 3:6076.

Bourke, R.H., Weigel, A.M., and Paquette, R.G., 1988. The westward turning branch of the West Spitsbergen Current. J. Geophys. Res., 93:1406514077.

Bütschli, O., 1885. Erster Band, Protozoa. In Dr. H.G. Bronn's Klassen und Ordnungen des Thier-Reichs, Wissenschaftlich dargestellt in Wort und Bild: Leipzig (C.F. Winter'sche Verlagsbuchhandlung), 865-1088.

Bujak, J.P., 1984. Cenozoic dinoflagellate cysts and acritarchs from the Bering Sea and northern North Pacific, Deep Sea Drilling Project, Leg 19. Micropaleontology, 30:180-212.

Cande, S.C., and Kent, D.V., 1992. A new geomagnetic polarity time scale for the Late Cretaceous and Cenozoic. J. Geophys. Res., 97:1391713951. 
Clark, D.L., 1990a. Arctic Ocean ice cover: geologic history and climatic significance. In Grantz, A., Johnson, L., and Sweeney, J.F. (Eds.), The Arctic Ocean Region. Geol. Soc. Am., 53-62.

, 1990b. Stability of the Arctic Ocean ice-cover and Pleistocene warming events: outlining the problem. In Bleil, U., and Thiede, J. (Eds.), Proc. 1988 NATO Adv. Res. Workshop on Geological History of the Polar Oceans: Arctic versus Antarctic., NATO ASI Ser., Ser. C, 308:273-287.

Clark, D.L., Chern, L.A., Hogler, J.A., Mennicke, C.M., and Atkins, E.D., 1990. Late Neogene climate evolution of the Central Arctic Ocean. Mar Geol., 93:69-94.

Cronin, T.M, Whatley, R.P., Wood, A., Tsukagoshi, A., Ikeya, N., Brouwers, E.M., and Briggs, W.M., Jr., 1993. Microfaunal evidence for elevated Pliocene temperatures in the Arctic Ocean. Paleoceanography, 8:161173.

Dale, A.L., and Dale, B., 1992. Dinoflagellate contributions to the sediment flux of the Nordic Seas. In Honjo, S. (Ed.), Dinoflagellate Contributions to the Deep Sea: Woods Hole (Woods Hole Oceanographic Inst.), Ocean Biocoenosis Ser. 5, 45-75.

Dale, B., 1976. Cyst formation, sedimentation, and preservation: factors affecting dinoflagellate assemblages in Recent sediments from Trondheimsfjord, Norway. Rev. Palaeobot. Palynol., 22:39-60.

1977. New observations on Peridinium faeroense Paulsen (1905), and classification of small orthoperidinioid dinoflagellates. $\mathrm{Br}$. Phycol. J., $12: 241-253$.

1985. Dinoflagellate cyst analysis of Upper Quaternary sediments in core GIK 15530-4 from the Skagerrak. Nor. Geol. Tidsskr., 65:97-102. 1992. Dinoflagellate contributions to the open ocean sediment flux. In Honjo, S. (Ed.), Dinoflagellate Contributions to the Deep Sea: Woods Hole (Woods Hole Oceanographic Inst.), Ocean Biocoenosis Ser. 5, 1-31.

Dale, B., and Fjellså, A., 1994. Dinoflagellate cysts as paleoproductivity indicators: state of the art, potential, and limits. In Zahn, R., Pedersen, T.F., Kaminski, M.A., and Labeyrie, L. (Eds.), Carbon Cycling in the Glacial Ocean: Constraints on the Ocean's Role in Global Change: Berlin (Springer), NATO ASI Ser. I, 521-537.

Deflandre, G., 1937. Microfossiles des silex crétacés. Deuxième partie. Flagellés incertae sedis. Hystrichosphaeridés. Sarcodinés. Organismes divers. Ann. Paléontol., 26:51-103.

Deflandre, G., and Cookson, I.C., 1955. Fossil microplankton from Australian late Mesozoic and Tertiary sediments. Aust. J. Mar. Freshwater Res., 6:242-313.

de Vernal, A., Londeix, L., Mudie, P.J., Harland, R., Morzadec-Kerfourn, M.T., Turon, J.-L., and Wrenn, J.H., 1992. Quaternary organic-walled dinoflagellate cysts of the North Atlantic Ocean and adjacent seas: ecostratigraphy and biostratigraphy, In Head, M.J., and Wrenn, J.H. (Eds.), Neogene and Quaternary Dinoflagellate Cysts and Acritarchs: Salt Lake City (Publisher's Press), 289-328.

de Vernal, A., Turon, J.-L., and Guiot, J., 1994. Dinoflagellate cyst distribution in high-latitude marine environments and quantitative reconstruction of sea-surface salinity, temperature, and seasonality. Can. J. Earth Sci., 31:48-62.

Ehrenberg, C.G., 1831. Animalia evertebrata. In Hemprich, P.C., and Ehrenberg, C.G. (Eds.) Symbolae Physicae. Pars Zoologica. K. Akad. Wiss. Berlin Abh., 1831.

Eldholm, O., Thiede, J., Taylor, E., et al., 1989. Proc. ODP, Sci. Results, 104: College Station, TX (Ocean Drilling Program).

Evitt, W.R., 1963. A discussion and proposals concerning fossil dinoflagellates, hystrichospheres, and acritarchs, I. Proc. Nat. Acad. Sci. Wash., 49:158-164.

Fensome, R.A., Taylor, F.J.R., Norris, G., Sarjeant, W.A.S., Wharton, D.I., and Williams, G.L., 1993. A classification of living and fossil dinoflagellates. Micropaleontol., Spec. Publ., 7.

Haeckel, E., 1894. Entwurf eines natürlichen Systems der Organismen auf Grund ihrer Stammesgeschichte. Erster Teil: Systematische Phylogenie der Protisten und Pflanzen: Berlin (Georg Reimer).

Harland, R., 1979. Dinoflagellate biostratigraphy of Neogene and Quaternary sediments at Holes 400/400A in the Bay of Biscay (Deep Sea Drilling Project Leg 48). In Montadert, L., Roberts, D.G., et al., Init. Repts. DSDP, 48: Washington (U.S. Govt. Printing Office), 531-545.

1983. Distribution maps of recent dinoflagellate cysts in bottom sediments from the North Atlantic Ocean and adjacent seas. Palaeontol ogy, 26:321-387.
1994. Dinoflagellate cysts from the glacial/postglacial transition in the northeast Atlantic Ocean. Palaeontology, 37:263-283.

Harland, R., Reid, P.C., Dobell, P., and Norris, G., 1980. Recent and subRecent dinoflagellate cysts from the Beaufort Sea, Canadian Arctic. Grana, 19:211-225.

Head, M. (Ed.), 1993. A forum on Neogene and Quaternary dinoflagellate cysts (the edited transcript of a round table discussion held at the Third Workshop on Neogene and Quaternary Dinoflagellates; with taxonomic appendix). Palynology, 17:201-239.

Head, M.J., 1994. Morphology and paleontological significance of the Cenozoic dinoflagellate genera Tectatodinium and Habibacysta. Micropaleontology, 40:289-321.

Head, M.J., Norris, G., and Mudie, P.J., 1989. New species of dinocysts and new species of acritarch from the Upper Miocene and Lowermost Pliocene, ODP Leg 105, Site 646, Labrador Sea. In Srivastava, S.P., Arthur, M.A., Clement, B., et al., Proc. ODP, Sci. Results, 105: College Station, TX (Ocean Drilling Program), 453-466.

Head, M.J., and Wrenn, J.H. (Eds.), 1992. A forum on Neogene and Quaternary dinoflagellate cysts (the edited transcript of a round table discussion held at the Second Workshop on Neogene and Quaternary Dinoflagellates. In Head, M.J., and Wrenn, J.H. (Eds.), Neogene and Quaternary Dinoflagellate Cysts and Acritarchs: Salt Lake City (Publisher's Press), $1-31$.

Henrich, R., and Baumann, K.H. 1994. Evolution of the Norwegian Current and the Scandinavian Ice Sheets during the past $2.6 \mathrm{~m} . \mathrm{y}$.: evidence from ODP Leg 104 biogenic carbonate and terrigenous records. Palaeogeogr. Palaeoclimatol., Palaeoecol., 108:75-94.

Herman, Y., Osmond, J.K., and Somayajulu, B.L.K., 1989. Late Neogene Arctic paleoceanography: micropaleontology, stable isotopes and chronology. In Herman, Y. (Ed.), The Arctic Seas: Climatology, Oceanography, Geology and Biology, New York (Van Nostrand Reinhold), 581-655.

Hunkins, K., 1990. A review of the physical oceanography of Fram Strait. In Pratt, L.J. (Ed.), The Physical Oceanography of Sea Straits: Dordrecht (Kluwer Acad. Publ.), 61-93.

Indelicato, S.R., and Loeblich, A.R., III, 1986. A revision of the marine peridinoid genera (Pyrrophyta) utilizing hypothecal-cingular plate relationships as a taxonomic guideline. Jpn. J. Phycol., 34:153-162.

Jan du Chêne, R., 1977. Etude palynologique du Miocène supérieur Andalou (Espagne). Rev. Espan. Micropaleontol., 9:97-114.

Jansen, E., Bleil, U., Henrich, R., Kringstad, L., and Slettemark, B., 1988. Paleoenvironmental changes in the Norwegian Sea and Northeast Atlantic during the last 2.8 m.y.: Deep Sea Drilling Project/Ocean Drilling Program Sites 610, 642, 643, and 644. Paleoceanography, 3:563-581.

Lankester, E.R., 1885. Protozoa. In The Encyclopedia Britannica (9th ed.), 19:830-866.

Lentin, J.K., and Williams, G.L., 1993. Fossil dinoflagellates: index to genera and species, 1993 edition. Am. Assoc. Stratigr. Palynol. Contrib., $28: 1-856$

Lindemann, E., 1928. Abteilung Peridineae (Dinoflagellatae). In Engler, A. and Prantl, K. (Eds.), Die natürlichen Pflanzenfamilien nebst ihren Gatttunungen und wichtigeren Arten insbesondere den Nutzpflanzen: Leipzig (Wilhelm Engelmann), 3-104.

Manley, T.O., Bourke, R.H., and Hunkins, K.L., 1992. Near-surface circulation over the Yermak Plateau in northern Fram Strait. J. Mar. Sys., 3:107125

Mantell, G.A., 1850. A Pictorial Atlas of Fossil Remains Consisting of Coloured Illustrations Selected from Parkinson's "Organic Remains of a Former World," and Artist's "Antediluvian phytology." London (Henry G. Bohn).

Matsuoka, K., 1983. Late Cenozoic dinoflagellates and acritarchs in the Niigata District, Central Japan. Palaeontographica B, 187:89-154.

Matsuoka, K., and Bujak, J.P., 1988. Cenozoic dinoflagellate cysts from the Navarin Basin, Norton Sound and St. George Basin, Bering Sea. Bull. Fac. Lib. Arts, Nagasaki Univ., Nat. Sci., 29:1-147.

Matthiessen, J., 1991. Dinoflagellaten-Zysten im Spätquartär des Europäischen Nordmeeres: Palökologie und Paläo-Ozeanographie. Geomar Rep., 7:1-104.

, 1995. Distribution patterns of dinoflagellate cysts and other organic-walled microfossils in recent Norwegian-Greenland Sea sediments. Mar. Micropaleontol., 24:307-334.

Mudie, P.J., 1992. Circum-Arctic Quaternary and Neogene marine palynofloras: paleoecology and statistical analysis. In Head, M.J., and Wrenn, J.H. (Eds.), Neogene and Quaternary Dinoflagellate Cysts and Acritarchs: Salt Lake City (Publisher's Press), 347-390. 
Mudie, P.J., de Vernal, A., and Head, M.J., 1990. Neogene to Recent palynostratigraphy of Circum-Arctic basins: results of ODP Leg 104, Norwegian Sea, Leg 105, Baffin Bay, and DSDP Site 611, Irminger Sea. In Bleil, U., and Thiede, J. (Eds.), Proc. 1988 NATO Adv. Res. Workshop on Geological History of the Polar Oceans: Arctic versus Antarctic., NATO ASI Ser., Ser. C, 308:609-646.

Myhre, A.M., Thiede, J., Firth, J.V., et al., 1995. Proc. ODP, Init. Repts., 151: College Station, TX (Ocean Drilling Program).

Pascher, A., 1914. Über Flagellaten und Algen. Ber. Dtsch. Bot. Ges., $36: 136-160$

Perkin, R.G., and Lewis, E.L., 1984. Mixing in the West Spitsbergen Current. J. Phys. Oceanogr, 14:1315-1325.

Poore, R.Z., Phillips, R.L., and Rieck, H.J., 1993. Paleoclimatic record for Northwind Ridge, western Arctic Ocean. Paleoceanography, 8:149-159.

Reid, P.C., 1977. Peridiniacean and Glenodiniacean dinoflagellate cysts from the British Isles. Nova Hedwigia, 29:429-463.

Rochon, A., and de Vernal, A., 1994. Palynomorph distribution in Recent sediments from the Labrador Sea. Can. J. Earth Sci., 31:115-127.

Rossignol, M., 1964. Hystrichosphères du Quaternaire en Méditerranée orientale, dans les sédiments Pléistocènes et les boues marine actuelles. Rev. Micropaléontol., 7:83-89.

Samtleben, C., Schäfer, P., Andruleit, H., Baumann, A., Baumann, K.-H., Kohly, A., Matthiessen, J., and Schröder-Ritzrau, A., 1995. Plankton in the Norwegian-Greenland Sea: from living communities to sediment assemblages-an actualistic approach. Geol. Rundsch., 84:108-136.

Sarjeant, W.A.S., 1970. The genus Spiniferites Mantell, 1850 (Dinophyceae). Grana, 10:74-78.

Schiller, J., 1935. Dinoflagellatae (Peridineae) in monographischer Behandlung. 2. Teil, Lieferung 2. In Kolkwitz, R. (Ed.), Zehnter Band. Flagellatae. In Rabenhorst, L. (Ed.), Kryptogamen-Flora von Deutschland, Österreich und der Schweiz: Leipzig (Akademische Verlagsgesellschaft), 161-320.
Scott, D.B., Mudie, P.J., Baki, V., MacKinnon, K.D., and Cole, F.E., 1989 Biostratigraphy and late Cenozoic paleoceanography of the Arctic Ocean: foraminiferal, lithostratigraphic, and isotopic evidence. Geol. Soc. Am. Bull., 101:260-277.

Stockmarr, J., 1971. Tablets with spores used in absolute pollen analysis. Pollen et Spores, 13:615-621.

Stover, L.E., and Evitt, W.R., 1978. Analyses of pre-Pleistocene organicwalled dinoflagellates. Stanford Univ. Publ. Geol. Sci., 15:1-300.

Taylor, F.J.R., 1980. On dinoflagellate evolution. BioSystems, 13:65-108.

Vinje, T.E., 1983. Sea-ice conditions in 1982. Aarb., Nor. Polarinst. 1982:49-53.

Wall, D., 1965. Modern hystrichospheres and dinoflagellate cysts from the Woods Hole region. Grana Palynol., 6:297-314.

, 1967. Fossil microplankton in deep-sea cores from the Caribbean Sea. Palaeontology, 10:95-123.

Wall, D., and Dale, B., 1968. Modern dinoflagellate cysts and evolution of the Peridiniales. Micropaleontology, 14:265-304.

Wall, D., Dale, B., Lohmann, G.P., and Smith, W.K., 1977. The environmental and climatic distribution of dinoflagellate cysts in modern marine sediments from regions in the North and South Atlantic Oceans and adjacent seas. Mar. Micropaleontol., 2:121-200.

Wilson, G.J., 1973. Palynology of the middle Pleistocene Te Piki bed, Cape Runaway, New Zealand. N. Z. J. Geol. Geophys., 16:345-354.

Date of initial receipt: 7 July 1995

Date of acceptance: 15 December 1995

Ms 151SR-109 

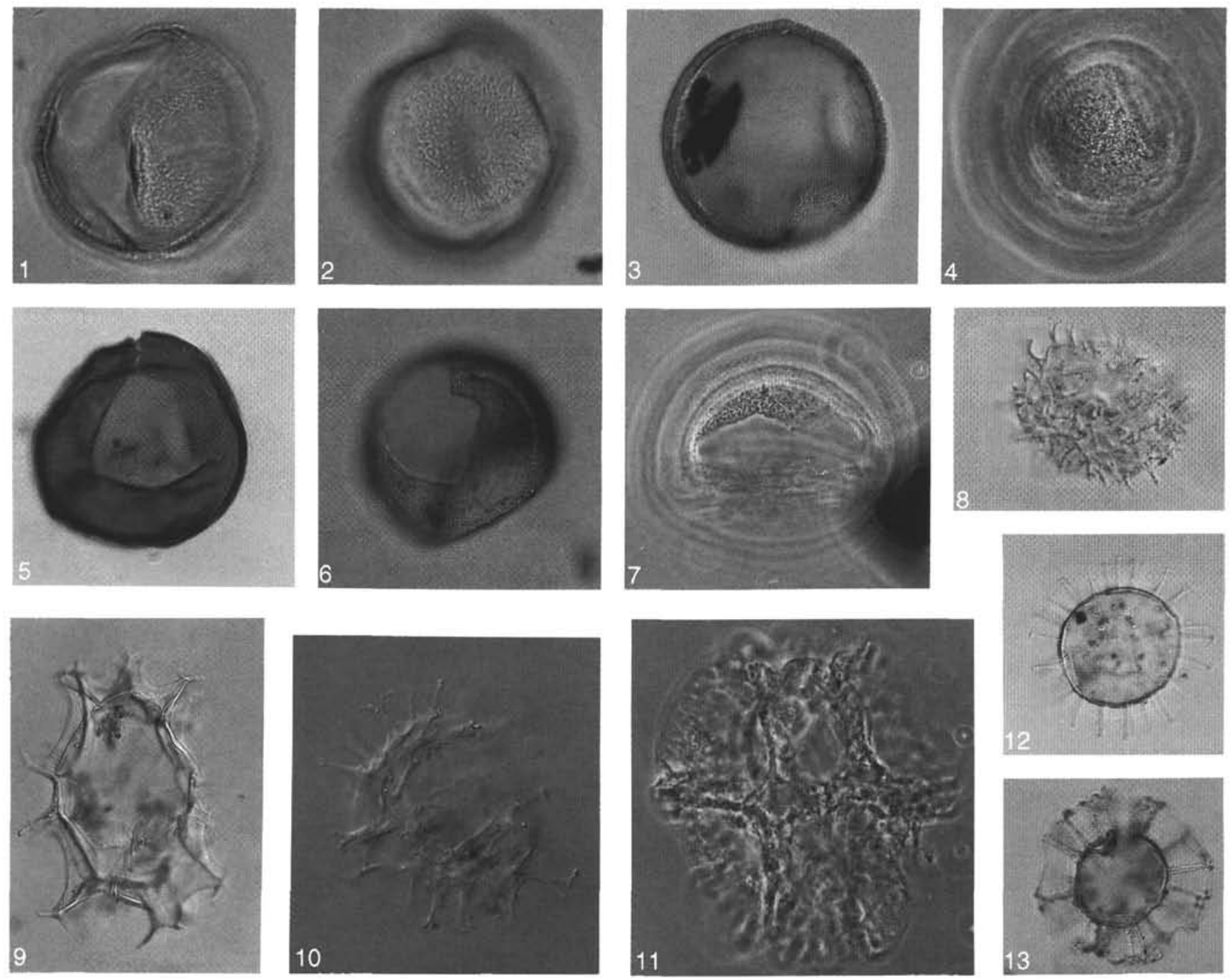

Plate 1. (Number after sample is slide number. The alphanumeric code is the England finder coordinate. Figs. $1-3,5,6,8,9,11=$ interference contrast; Figs. 4 , 7, 10, 12, 13 = phase contrast.) 1, 2. Habibacysta tectata: Sample 151-911A-32X-4, 69-75 cm, 1, P38; diameter $36 \mu \mathrm{m}$. (1) left lateral view, low focus, (2) right lateral view, high focus. 3, 4. Filisphaera filifera s.l.: Sample $151-911 \mathrm{~A}-16 \mathrm{X}-4,70-76 \mathrm{~cm}, 1$, U34/1; diameter $55 \mu \mathrm{m}$. (3) dorsal-ventral view, optical section, (4) ventral view, high focus. 5. Brigantedinium simplex: dorsal view, high focus, Sample 151-911A-35X-3, 69-75 cm, 1, N38/3; diameter 50 $\mu \mathrm{m}$. 6, 7. Bitectatodinium tepikiense: (6) right lateral view, high focus, Sample 151-911A-13H-4, 71-77 cm, 1, L24/1-3; diameter $38 \mu \mathrm{m}$. (7) surface ornamentation, dorsal view, high focus, Sample 151-911A-11H-4, 72-78 cm, 1; N24/2, diameter $50 \mu \mathrm{m}$. 8. Acritarch sp. A: orientation unknown, optical section, Sample 151-911A$5 \mathrm{H}-4,77-83 \mathrm{~cm}, 2, \mathrm{~N} 34 / 1$; diameter (without processes) $25 \mu \mathrm{m}$. 9. Spiniferites elongatus s.1.: left lateral view, optical section, Sample 151-911 A-15H-4, 70-76 $\mathrm{cm}, 1, \mathrm{~S} 30 / 1$; size (without processes) $58 \times 35 \mu \mathrm{m}$. 10. Pentapharsodinium $\mathrm{cf}$. dalei: orientation unknown, optical section, Sample 151-911A-23X-4, 77-83 cm, 1, F32/4; diameter (without processes) $30 \mu \mathrm{m}$. 11. Impagidinium? pallidum: dorsal view, showing archeopyle, low focus, Sample 151-911A-36X-4, 67-73 cm, 2, M30/1; size $77 \times 70 \mu \mathrm{m} .12$. Operculodinium centrocarpum: right lateral view, optical section, Sample 151-911A-5H-4, 68-74 cm, 1, P34; diameter (without processes) $30 \mu \mathrm{m}$. 13. Nematosphaeropsis labyrinthus: orientation unknown, optical section, Sample $151-911 \mathrm{~A}-9 \mathrm{H}-4,82-88 \mathrm{~cm}, 1$, Q38/1; diameter (without processes) $25 \mu \mathrm{m}$. 